\title{
Kimmeridge Clay Ostracoda of the North Wootton Borehole, Norfolk, England
}

\author{
IAN P. WILKINSON \\ Institute of Geological Sciences, Nicker Hill, Keyworth, Nottingham NG12 5GG, England.
}

\begin{abstract}
Ostracoda frorn the Kimmeridge Clay Formation (Upper Jurassic) of the North Wootton Borehole was examined from a biostratigraphical point of view. The ostracod zonal scheme, previously erected for the stratotype section in Dorset, is modified and the faunas are related to the 47 beds which can be recognised by a combination of macrofaunal and lithological characteristics. Seven ostracod assemblage zones are recognised in the borehole, of these three are new and one is subdivided into two subzones. One new genus, Micrommatocythere, together with four new species and one new subspecies-Micrommatocythere edmundi, Paranotacythere (Unicosta) effusa, Mandelstamia (Xeromandelstamia) horrida, Macrodentina (Polydentina) woottonensis and Galliaecytheridea mandelstami kilenyii-are described.
\end{abstract}

\section{INTRODUCTION}

The Kimmeridge Clay of Norfolk is poorly represented at outcrop due to the thick and extensive drift deposits which blanket the region. As a consequence, prior to the recent work on borehole material by Gallois \& Cox (1974, 1976), Gallois (1979a, b) and Cope (1974), little information had been published since 1815 when William Smith called the formation The Oaktree Clay. It was mentioned by Rose (1835) and in the Memoirs of the Geological Survey (Whitaker, Skertchly \& Jukes-Browne, 1893; Woodward, 1895, and Strahan, $1920)$ as well as by Pringle (1923) and Kent (1947) in connection with drilling programmes for hydrocarbon exploration.

The gently folded Kimmeridge Clay of Norfolk, which disconformably overlies the Ampthill Clay (Oxfordian) and is itself overlain unconformably by the "Lower Greensand" Sandringham Sands (Portlandian), is attenuated on to the London-Brabant Massif. The thickness varies from approximately $130 \mathrm{~m}$ in The Wash to about $100 \mathrm{~m}$ at North Wootton [TF 64392457 ] and $56 \mathrm{~m}$ at Denver Sluice [ TF 59110106 ], near Downham Market, before disappearing to the south east of Mundford (Gallois \& Cox, 1974, Gallois, 1979b) (Fig. 1). This southward reduction in thickness is accentuated by the erosion of the top of the Upper Kimmeridge Clay which took place prior to the deposition of the Sandringham Sands.

The most complete sequence of Kimmeridge Clay in eastern England yet described is the continuously cored North Wootton Borehole (Grid Ref. TF 6439 2457), situated $5 \mathrm{~km}$ to the north east of Kings Lynn (Fig. 1). Between the depths 19.75 and $119.45 \mathrm{~m}$, the entire sequence from the baylei to the lower part of the pecti- natus ammonite zones of the Kimmeridgian has been proved. Thirty five beds in the Lower and 12 beds in the Upper Kimmeridge Clay have been recognised on the basis of a combination of macrofaunal and lithological characteristics (Gallois \& Cox, 1976; Gallois, 1979a). These beds are cyclic in nature - with silts or silty mudstones (kerogen-rich at some intervals) fining upwards to dark grey mudstones and finally, as a result of an increase in the calcium carbonate content, to pale grey mudstones. The rhythms can be traced over large distances and used to correlate the Kimmeridge Clay in East Anglia with the stratotype of Dorset (Cox \& Gallois, 1981) and boreholes in Wiltshire and Lincolnshire.

Although the upper part of the pectinatus ammonite Zone and above is absent, the excellent faunal and lithological control in the North Wootton Borehole, provides an extremely good standard for eastern England.

\section{PREVIOUS RESEARCH}

Kimmeridge Clay Ostracoda of the Dorset coast of southern England have been well documented in the last 25 years, initially by German workers (Malz, 1958a, 1958b; Glashoff, 1964), but later by Kilenyi (1965, 1969,1978 ) and Christensen \& Kilenyi (1970). Virtually all of this work has concentrated on the stratotype sections of the Kimmeridge Bay area, Dorset, and until now there has been a paucity of information about ostracod faunas from eastern England.

Ostracoda from the stratotype area have been shown to be extremely useful biostratigraphically by Christensen \& Kilenyi (1970). Their zonal scheme has been used, more or less successfully, over much of North West Europe including the North German Basin, North West 


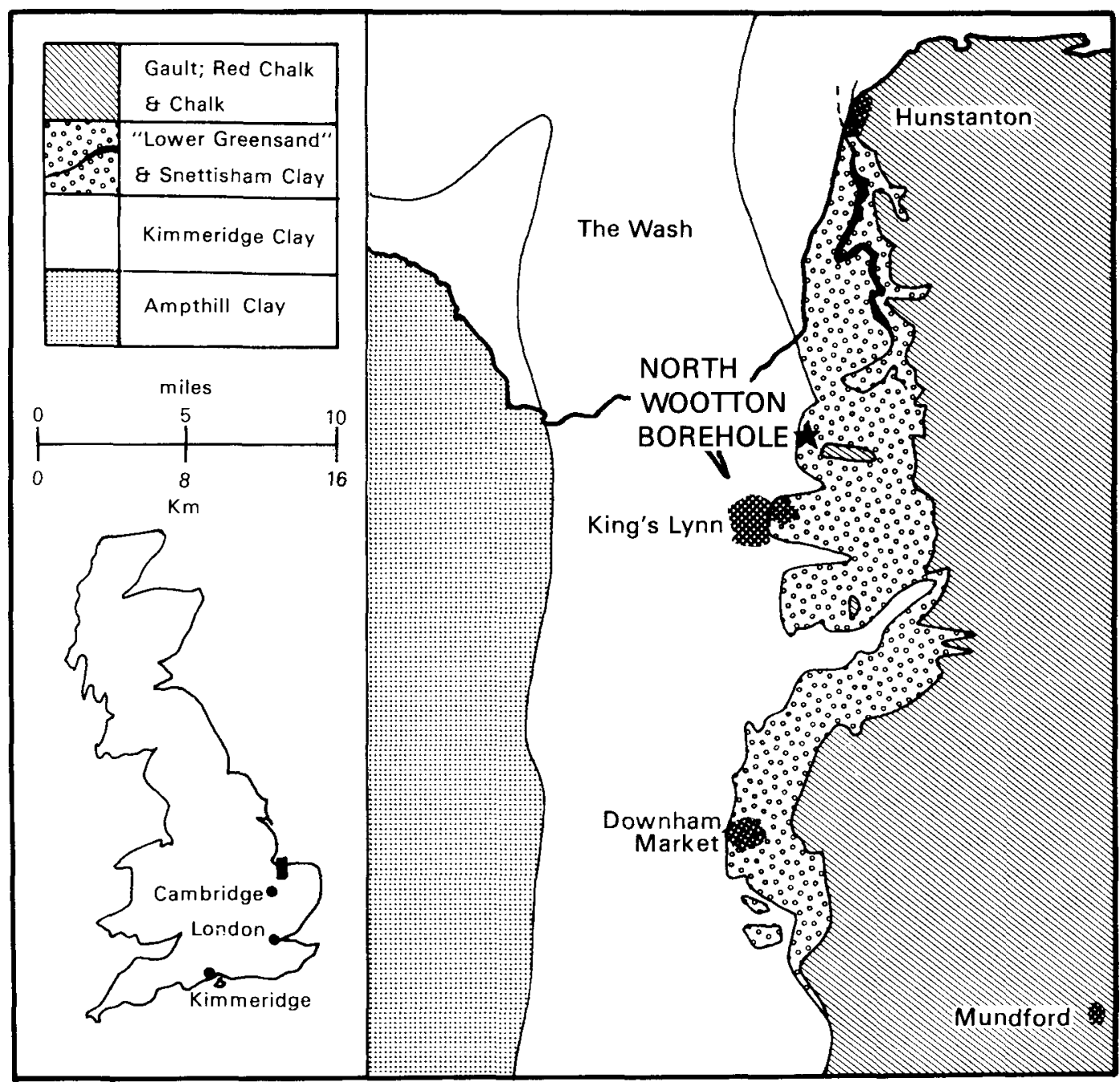

Fig. 1. Sketch map of the solid geology of eastern Norfolk and location of the North Wootton Borehole.

Polish Basin, North West Danish Embayment and Paris Basin. Although much of the eudoxus to lower part of the wheatleyensis ammonite zones are barren of Ostracoda and the wheatleyensis to pectinatus ammonite zones yield only poor assemblages, five ostracod assemblage zones were recognised. Later a sixth ostracod zone was added by Christensen (1974), the Galliaecytheridea compressa Zone. The relationship between the Dorset and Norfolk ostracod zonal schemes together with the ammonite zonation is summarised in Table 1.

\section{OSTRACODA FROM THE NORTH WOOTTON BOREHOLE}

\section{Lower Kimmeridge Clay Ostracoda}

The Lower Kimmeridge Clay in the North Wootton Borehole extends from a depth of 119.40 to $51.15 \mathrm{~m}$ and comprises the baylei to autissiodorensis ammonite zones and Beds 1-35 of Gallois \& Cox (1976). In its upper part
(Beds 29 and 31-35) oil shales are common, the thickest seams being found near the top of the eudoxus ammonite Zone, Bed 32. It is at this interval that the ostracod faunas become sparse or barren, nevertheless stratigraphically significant assemblages have been recovered throughout most of the sequence (Fig. 2). Diversity was found to be low-of the 39 samples examined the majority had a diversity of five or less and only eight samples exceeded ten.

The zonal scheme of Christensen \& Kilenyi (1970) is recognisable but, in the light of new evidence from the North Wootton Borehole, it is in part modified.

a. The Galliaecytheridea dissimilis ostracod Zone. The lowest ostracod zone of the Kimmeridge Clay, the Galliaecytheridea dissimilis Zone, is represented by the $119.40-100.39 \mathrm{~m}$ interval of the North Wootton Borehole. It encompasses the baylei, cymodoce and lowest part of the mutabilis ammonite zones and corre- 
sponds with Beds 1-15 of Gallois \& Cox (1976). Although $G$. dissimilis was not encountered in the lowest two beds, its almost consistent occurrence in large numbers in Beds 3-15 renders it an excellent marker. It is commonly found associated with the long ranging species $G$. dorsetensis, $G$. postrotunda, Schuleridea triebeli (a species which exhibits precocious sexual dimorphism), Dicrorygma reticulata and Paranotacythere extendata.
In Beds 1 and 2, at the base of the baylei ammonite Zone, Macrodentina pulchra was recovered in large numbers. This species has been recorded from the Upper Oxfordian and the lowest part of the baylei ammonite zones in N.W. Germany, but only from the Upper Oxfordian of Dorset (Glashoff, 1964). Its presence in the North Wootton Borehole brings its known range in Britain into line with that of N.W. Europe.

\begin{tabular}{|c|c|c|c|c|}
\hline & & \multicolumn{3}{|c|}{ ostracod zones } \\
\hline stage & ammonite zones & $\begin{array}{l}\text { Christensen \& } \\
\text { Kilenyi (1971); } \\
\text { Christensen (1974); } \\
\text { Kilenyi (1978). }\end{array}$ & \multicolumn{2}{|c|}{ This paper } \\
\hline \multirow{9}{*}{ 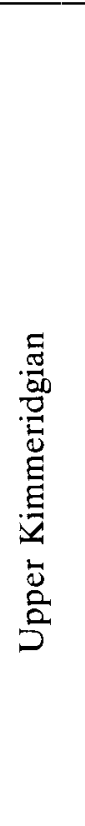 } & \multirow{2}{*}{$V$. fittoni } & G. compressa & & \\
\hline & & G. polita & & \\
\hline & $P$. rotunda & & & \\
\hline & P. pallasioides & G. spinosa & niatus & \\
\hline & P. pectinatus & & un-name & ----- \\
\hline & P. hudlestoni & M. maculata & E. aquita & \\
\hline & P. wheatleyensis & ----------- & M. macu & \\
\hline & P. scitulus & & M. horric & \\
\hline & P. elegans & $\begin{array}{l}\text { Barren } \\
\text { of } \\
\text { Ostracoda }\end{array}$ & un-name & ---- \\
\hline & A. autissiodorensis & & & \\
\hline$\frac{5}{80}$ & A. eudoxus & $---\cdots--$ & $G$ & $\begin{array}{l}M \\
\text { steghausi }\end{array}$ \\
\hline$\stackrel{\breve{E}}{E}$ & $A$ muhilis & G. elongata & enongaia & G. M. kilenyii \\
\hline$\stackrel{\bar{\Xi}}{\Xi}$ & A. Mataotis & & M. procli & \\
\hline $\bar{u}$ & R. cymodoce & G. dissimilis & & \\
\hline & P. baylei & & & \\
\hline
\end{tabular}

Table 1. A comparison of the ostracod zonal schemes in Dorset and Norfolk and their relationship to the zonation by ammonites. 


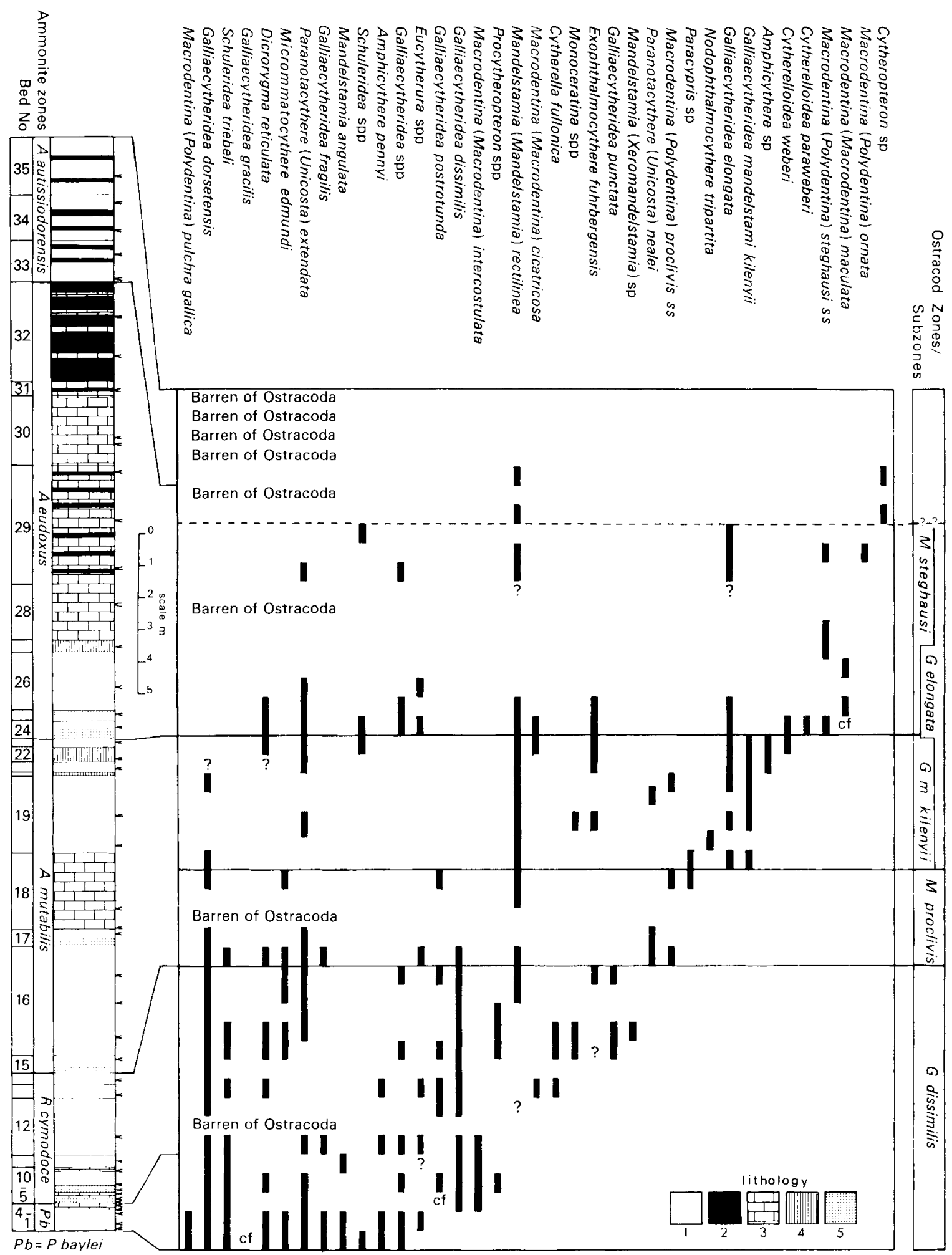

Fig. 2 Distribution of the Ostracoda recovered from the Lower Kimmeridge Clay of the North Wootton Borehole (lithological log, ammonite zones and Bed numbers after Gallois and Cox, 1976). Lithology: 1 . mudstone, dark and medium grey; 2 . oil shale; 3 . Pale grey, very calcareous mudstones; 4 . very shelly mudstone; 5 . silty mudstone. 
C. dissimilis occurs in flood proportions between Beds 3 and 5 (upper part of the baylei and basal cymodoce zones) at depths of 118.80-117.55 m, where it is frequently found with Macrodentina intercostulata. This latter species is diagnostic of deposits ranging from the Upper Oxfordian to the lowest part of the baylei ammonite zone of N.W. Europe (Glashoff, 1964), but the highest record in the present borehole is the basal part of the cymodoce ammonite Zone (Bed 5).

The ostracod faunas of Beds 5-9 in the cymodoce ammonite Zone are sparse, but $G$. dissimilis is generally present and in the upper part Macrodentina (M.) cicatricosa and Cytherella fullonica have also been noted. Rich assemblages were recovered from the upper part of the cymodoce Zone (Beds 10-14, 11.5-109.8 m depth) where Galliaecytineridea punctata, a characteristic species of the baylei and cymodoce ammonite zones (Kilenyi, 1969) was recovered. Although two damaged instars tentatively assigned to Mandelstamia rectilinea were recovered from Bed 7 , from a depth of $117.0 \mathrm{~m}$, the species occurred commonly for the first time in Bed 13 (at $110.7 \mathrm{~m}$ ). This species is restricted to the mutabilis and basal eudoxus ammonite zones of Dorset (Christensen \& Kilenyi, 1970, fig. 2) but it has also been recorded from the Upper Oxfordian (Glashoff, 1964; Whatley, 1965).

b. The Macrodentina (Polydentina) proclivis ostracod Zone. Galliaecytheridea dissimilis extends into the lower mutabilis ammonite Zone, Bed 15, where it occurs in small numbers. The extinction level in the borehole is taken to be at the top of this bed, at a depth of $108.20 \mathrm{~m}$, at approximately the same stratigraphical level as in Dorset. Between 107.10 and $99.0 \mathrm{~m}$ (Beds 16-18), asse mblages were sparse and of very low diversity $(6$ in Bed 17, but less than 3 elsewhere). Specimens of the index species of the Galliaecytheridea elongata ostracod Zone of Christensen \& Kilenyi (1970) were not recovered and this gap in the zonal scheme also occurs near the base of the mutabilis ammonite Zone in Dorset (Kilenyi, 1969). It is here proposed that a new zone is erected to fill this gap.

The low diversity of the assemblages restricts the choice of the index species to Macrodentina (Polydentina) proclivis, which first appears at the base of the mutabilis ammonite Zone in the North Wootton Borehole as well as in Dorset (Kilenyi, 1969). The zone fossil is not common, but was recovered from Bed 15 , where it occurred with $G$. dissimilis, Bed 17 and again in Bed 21 where it was found together with G. elongata. Within the Macrodentina (Polydentina) proclivis ostracod Zone, numerous long ranging species become extinct-Schuleridea triebeli, Galliaecytheridea fragilis, G. postrotunda and Micrommatocythere edmundi as well as, at the base, G. dissimilis.

c. The Galliaecytheridia elongata ostracod Zone. The îrst occurrence of the ostracod zone fossil, $G$. elongata, in Dorset is in the middle part of the mutabilis ammonite Zone, a little below Bed 22, the Supracorallina Bed (Kilenyi, 1969). In the North Wootton Borehole, the first appearance of the zone fossil is at the base of Bed 18 , at a depth of $100.3 \mathrm{~m}$, although it is rare until Bed 21 (Bed 20 was too thin to be sampled for micropalaeontological examination). The upper boundary of the ostracod Zone is a little below the top of the eudoxus ammonite Zone, in Bed 31, but the highest bed of the eudoxus Zone (Bed 32), being composed almost entirely of oil shale, contains a very sparse, poorly preserved fauna.

The ostracod assemblages of the G. elongata ostracod Zone of the North Wootton Borehole, fall into two subzones. The lower is characterised by the association of $G$. mandelstami kilenyii subsp. nov. with $G$. elongata from the base of the ostracod Zone up to Bed 23, at the top of the mutabilis ammonite Zone. The upper subzone is recognised by the first appearance of Macrodentina (Polydentina) steghausi steghausi $(=M$. (P.) proclivis striata of Kilenyi, 1969) which extends from Bed 24 to Bed 30.

Within the $G$. mandelstami kilenyii ostracod Subzone, $G$. dorsetensis, Paranotocythere (Unicosta) nealei and Macrodentina (Polydentina) proclivis become extinct. A single specimen of Nodophthalmocythere tripartita was recovered from Bed 18 (from a depth of $99.00 \mathrm{~m}$ ) in the middle part of the mutabilis ammonite Zone and can be used to correlate this interval with Dorset (Kilenyi, 1969; Christensen \& Kilenyi, 1970) and perhaps the Paris Basin (Malz, 1958a). Cytherelloidea weberi was present at the top of the subzone (Bed 23).

The $M$. (P.) steghausi steghausi ostracod Subzone contains several species not seen in lower levels of the North Wootton Borehole. Amongst these are Macrodentina maculata and Cytherelloidea paraweberi which are present at a slightly lower stratigraphical level in Dorset (Kilenyi, 1969), but above the Supracorallina Bed (Bed 22 of Gallois \& Cox, 1976; Cox \& Gallois, 1981). The last occurrence of Dicrorygma reticulata, Exophthalmocythere fuhrbergensis and Paranotacythere (Unicosta) extendata is in this ostracod subzone. d. Un-named zone. The extinction level of $G$. elongata is in Bed 31, at the top of the eudoxus ammonite Zone. This is followed by an interval of thick oil shales which is generally barren of Ostracoda but with very sparse faunas at some levels. Mandelstamia rectilinea, which is extremely common throughout the mutabilis and eudoxus ammonite Zones (sometimes reaching flood proportions), is present in small numbers in Bed 32 and 33 where it is accompanied by very rare fragmentary Cytheropteron sp. The remainder of the Lower Kimmeridgian (autissiodorensis ammonite Zone, the upper part of Bed 33 to 35) of the North Wootton Borehole is barren of Ostracoda. 


\section{Upper Kimmeridge Clay Ostracoda}

The Upper Kimmeridge Clay extends from a depth of $51.15 \mathrm{~m}$ to the unconformable contact with the Sandringham Sands at $19.75 \mathrm{~m}$. It includes the elegans to the lower part of the pectinatus ammonite Zones, Beds 36-47 of Cox \& Gallois (in Gallois, 1979a). The lower part of the sequence was deposited under similar conditions to those at the top of the Lower Kimmeridge Clay and oil shales are common throughout the elegans and lowest part of the scitulus ammonite Zones (Beds 36 and 37). Ostracoda are sparse throughout most of the Upper Kimmeridge Clay, but where oil shale seams are absent or thin, small populations have been recovered. Diversities are always low, generally between one and three, but in Bed 45, at the top of the hudlestoni ammonite Zone, they were slightly higher at seven (Fig. 3).

a. Un-named zone. The elegans ammonite Zone (Bed 36) was barren of Ostracoda and in this respect identical to Dorset. Although the lower part of the scitulus ammonite Zone (Beds 37 and basal 38) was also barren of Ostracoda, the higher part of Bed 38 contained a very sparse fauna. Schuleridea moderata made its first appearance in the borehole at this level and the known range is therefore slightly extended; previously it had been recovered only from the hudlestoni and pectinatus ammonite zones of Dorset (Christensen \& Kilenyi, 1970). The rare specimens of Paranotacythere (Unicosta) sp. A have close affinities with $P$. (Unicosta) nealei and may be a phylogenetic link between that species and $P$. rimosa of the Portlandian.

b. The Mandelstamia (Xeromandelstamia) horrida ostracod Zone. The $M$. $(X)$.) horrida ostracod Zone extends from the upper part of Bed 38 to the basal part of Bed 40 (between 43.4 and $41.6-41.0 \mathrm{~m}$ ). Diversity is very low and Mandelstamia $(X$.) horrida sp. nov. is found in flood proportions (up to $99 \%$ ) in the lower part of the zone although the upper part is poorly fossiliferous. Paranotacythere (Unicosta) effusa sp. nov. occurs rarely in this zone, but extends up into the base of the succeeding zone where it forms $75 \%$ of the ostracod population.

c. The Mandelstamia (Xeromandelstamia) maculata ostracod Zone. In Dorset, Mandelstamia (X.) maculata is found in the wheatleyensis ammonite Zone, where it is restricted to the mudstones a little above the Grey Ledge Stone Band and slightly below The Blackstone (Kilenyi, 1969), Beds 41 and the base of 42 as defined by Cox \& Gallois (1981). In the North Wootton Borehole the species was recovered from the upper part of Bed 40 to Bed 42. It occurred in flood proportions at $39.2 \mathrm{~m}$ in the middle part of Bed 41 and within the thick oil shale at $35.1 \mathrm{~m}$ (Bed 42). With the exception of the sample from the very calcareous interval at the top of Bed 40 which has a diversity of 5 , samples from this zone were frequently almost monospecific. Very rare specimens of an angular Galliaecytheridea with a pointed, slightly spinose posterior, were recovered from Beds 40 and 42 and appear to be a form intermediate between $G$. mandelstami kilenyii and $G$. spinosa.

d. Un-named Zone. Between 35.0 and $33.25 \mathrm{~m}$, that is the upper part of Bed 42 and 43 , samples were very poorly fossiliferous or barren. Small numbers of Paranotacythere (Unicosta) sp. cf. nealei and Schuleridea moderata were recovered, but this interval could not be included in any of the named ostracod zones.

e. The Eocytheropteron aquitanum ostracod Zone. The paucity of the ammonite populations in Dorset, led Christensen \& Kilenyi (1970) to extend the $M$. (X.) maculata Zone up to the first occurrence of $G$. spinosa, although the ostracod zone fossil is absent above Bed 42 . Eocytheropteron aquitanum was recovered from the upper part of the hudlestoni ammonite Zone, Bed 44, in Dorset (Kilenyi, 1969) and it has also been recorded from L'île d'Oléron, near St. Denis (Donze, 1960) and between Cap de la Creche and Boulogne-sur-Mer (Oertli, 1963) although the exact stratigraphical positions are not clear. In the North Wootton Borehole, E. aquitanum was recovered from Bed 44, between 33.25 and $26.90 \mathrm{~m}$ and is used as the ostracod zone fossil corresponding with the middle and upper part of the hudlestoni ammonite Zone. It extends up into the basal part of the overlying ostracod zone where it is found together with $G$. spinosa.

f. The Galliaecytheridea spinosa ostracod Zone. In Dorset, the $G$. spinosa ostracod Zone ranges from the upper part of the pectinatus to the lower part of the fittoni ammonite Zones (Kilenyi 1969; Christensen \& Kilenyi, 1970). In the North Wootton Borehole, the nominate zone fossil first evolved during the latest hudlestoni ammonite Zone (Bed 45) but it was not recovered from the overlying pectinatus ammonite Zone (Beds 46 and 47). Mandelstamia (Xeromandelstamia) tumida is common in the lower part of Bed 45 and Macrodentina (Polydentina) woottonensis dominates the assemblage in the middle part. Faunas become sparse in the top of the bed, but at $22.5 \mathrm{~m}$ Schuleridea moderata occurs in flood proportions. Paranotacythere (Unicosta) pustulata and Mandelstamia (Xeromandelstamia) tumida occur at a lower stratigraphical level in this borehole compared to Dorset where they do not occur below the upper part of the pectinatus ammonite Zone (Bed 48) (Kilenyi, 1969; Christensen \& Kilenyi, 1970).

g. Un-named Zone. The uppermost $2.45 \mathrm{~m}$ of the Kimmeridge Clay in the North Wootton Borehole (Beds 46 and 47 ) has been assigned to the pectinatus ammonite Zone by Cox \& Gallois (in Gallois, 1979a). Whilst Bed 46 is barren of Ostracoda, very rare specimens of the long ranging species Schuleridea moderata have been recovered from Bed 47.

All specimens used in this study are housed with the Institute of Geological Sciences, Leeds, England. 


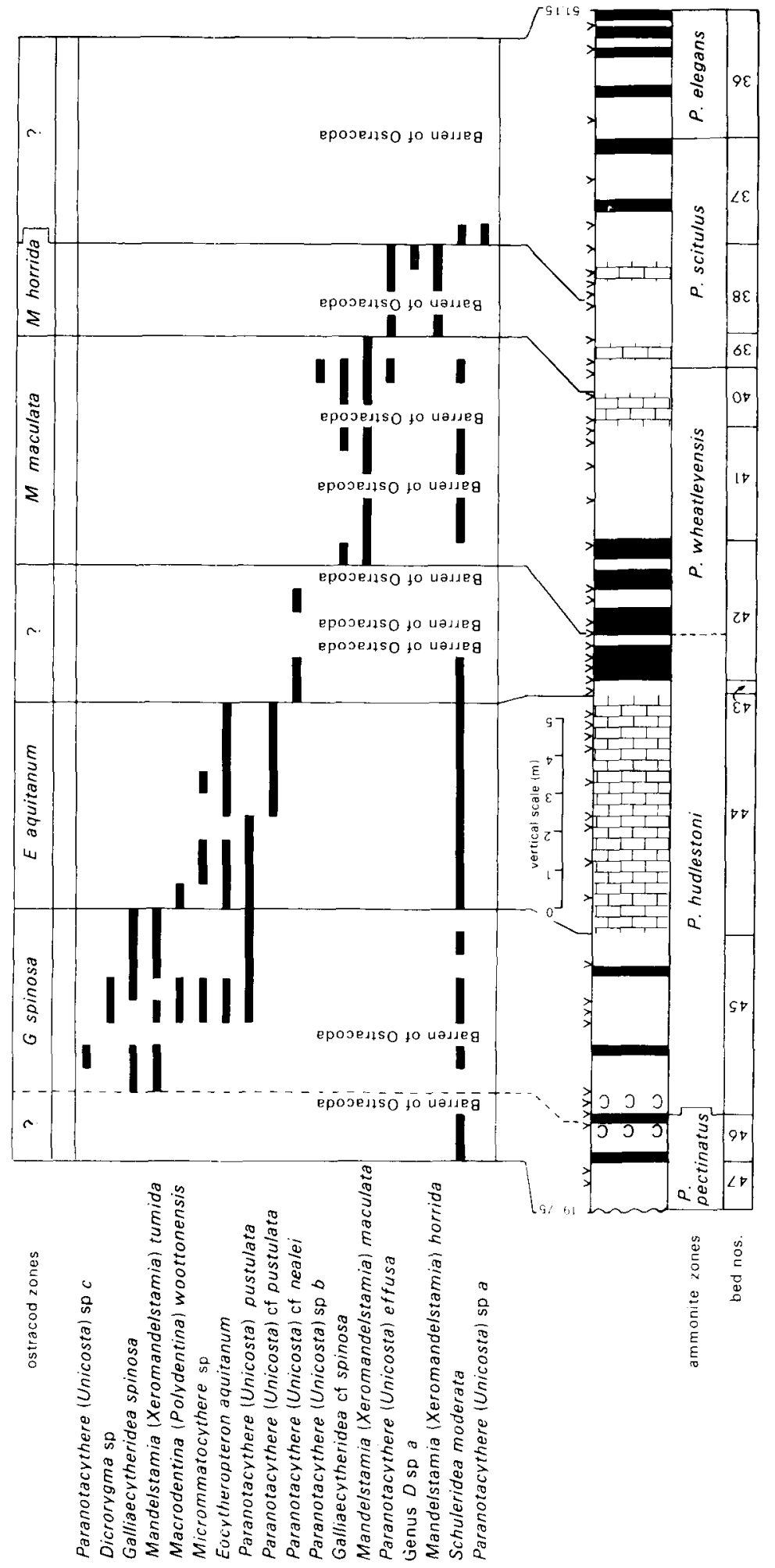

Fig. 3. Distribution of the Ostracoda recovered from the Upper Kimmeridge Clay of the North Wootton Borehole (lithological $\log$, ammonite zones and Bed numbers after Gallois and Cox in Gallois 1979a). For the key to the lithology, see text-fig. 2 . 


\section{SYSTEMATIC DESCRIPTIONS}

Suborder Podocopina Sars, 1866

Superfamily Cytheracea Baird, 1850

Family Brachycytheridea Puri, 1954

Genus Macrodentina Martin, 1940

Macrodentina (Polydentina) woottonensis sp. nov.

(Pl. 2, figs. 1-4)

Derivation of name. After North Wootton, the locality of the borehole from which the species was first recovered.

Diagnosis. Elongate, punctate species of Macrodentina (Polydentina) with straight ventral margin and sloping dorsal margin. Posterior obliquely truncate, angular. Surface coarsely punctate.

Holotype. MPK 3672 , LV, from the upper part of the hudlestoni Zone (E. aquitanum Ostracod Zone), Bed 45 , of the Upper Kimmeridge Clay at a depth of $24.60 \mathrm{~m}$ in the North Wootton Borehole.

Description. Carapace elongate. Ventral margin straight, dorsal margin straight and back-sloping. Anterior broadly rounded. Marked posterior cardinal angle and straight obliquely truncated posterodorsal margin gives an angular outline. Surface ornament of coarse punctations; round over much of the lateral surface, but slightly elongate near the ventral margin. Weak ribs extend along the ventral and anterior margins. Instars exhibit small, posteroventral and anteroventral spines. Weakly developed paramphidont hinge with crenulate terminal elements and smooth median ridge/groove with poorly formed anteromedian element. Muscle scars not visible. Sexual dimorphism not pronounced, but males are slightly more elongate than females.

$\begin{array}{ccc}\text { Dimensions (mm) } & \text { Length } & \text { Height } \\ \text { Holotype LV, MPK } 3672 & 0.65 & 0.33\end{array}$

Remarks. $M$. (P.) woottonensis differs from other species of the subgenus in its ornamentation and angular shape. It bears some superficial resemblance to $M$. (Macrodentina) klingleri Malz and $M$. (M.) transiens (Jones), but can be simply separated by the hinge structure. The species is restricted to Bed 45 of the Upper Kimmeridge Clay where it occurs in flood proportions.

Family Cytheruridae Muller, 1894

Genus Micrommatocythere gen. nov.

Type species. Micrommatocythere edmundi sp. nov. Derivation of name. From the Greek $\mu \iota \kappa \rho о \mu \mu \alpha \tau o s$, small eyed. (female).

Diagnosis. Valves elongate, drawn out posteriorly to form a dorsally situated caudal process. Dorsal margin straight; ventral margin sinuous, curving smoothly posteroventrally to the caudal process, anterior margin broadly rounded. Widest posterior of the mid length and highest at the anterior cardinal angle. Lateral surface weakly sulcate and weakly alate posteroventrally. Ornament finely punctate. Small, but distinct eye tubercle present. Inner margin moderately board;

\section{Explanation of Plate 1}

All figures are $\times 100$ unless otherwise specified

Figs. 1-2. Galliaecytheridea dissimilis Oertli: fig. 1, LV, MPK 3652; fig. 2, RV, MPK 3679 . Bed 3 (baylei ammonite Zone), depth $117.9 \mathrm{~m}$

Fig. 3. Macrodentina (Polydentina) proclivis proclivis Malz: RV, MPK 3653. Bed 15 (mutabilis ammonite Zone), depth $108.6 \mathrm{~m}(\times 88)$.

Fig. 4. Galliaecytheridea elongata Kilenyi: LV, MPK 3654, Bed 19 (mutabilis ammonite Zone), depth $95.1 \mathrm{~m}$.

Figs. 5-6. Galliaecytheridea mandelstami kilenyii ssp. nov.: fig. 5, car., left lateral view, holotype, MPK 3655; fig. 6, car., right lateral view, paratype, MPK 3676. Bed 22 (mutabilis ammonite Zone), depth $89.7 \mathrm{~m}$.

Fig. 7. Macrodentina (Polydentina) steghausi steghausi (Klingler): RV, MPK 3656, Bed 28 (eudoxus ammonite Zone) depth $80.1 \mathrm{~m}$.

Figs. 8-9. Mandelstamia (Mandelstamia) rectilinea Malz: fig. 8, q RV, MPK 3667 ( $\times 80)$; fig. 9, ơ LV, MPK 3668 ( $\times 65$ ). Bed 15 (mutabilis ammonite Zonc), depth $108.6 \mathrm{~m}$.

Fig. 10. Paranotacythere (Unicosta) extendata Bassiouni: LV, MPK 3675, Bed $1 / 2$ (baylei ammonite Zone), depth $119.1 \mathrm{~m}$.

Fig. 11. Macrodentina (Polydentina) pulchra gallica Glashoff: $\$$ LV, MPK 3662, Bed 1/2 (baylei ammonite Zone) depth $119.1 \mathrm{~m}$.

Fig. 12. Nodophthalmocythere tripartita Malz: car., right lateral view, MPK 3677, Bed 18 (mutabilis ammonite Zone) depth $99.0 \mathrm{~m}$.

Figs. 13-15. Micrommatocythere edmundi gen. et sp. nov.: fig. 13, car., right lateral view, holotype, MPK 3659; fig. 14, $\mathrm{RV}$, internal view, paratype, MPK 3660; fig. 15, car., left lateral view, paratype, MPK $3661(\times 200)$. Bed 11 (cymodoce ammonite Zone), depth $114.9 \mathrm{~m}$. 


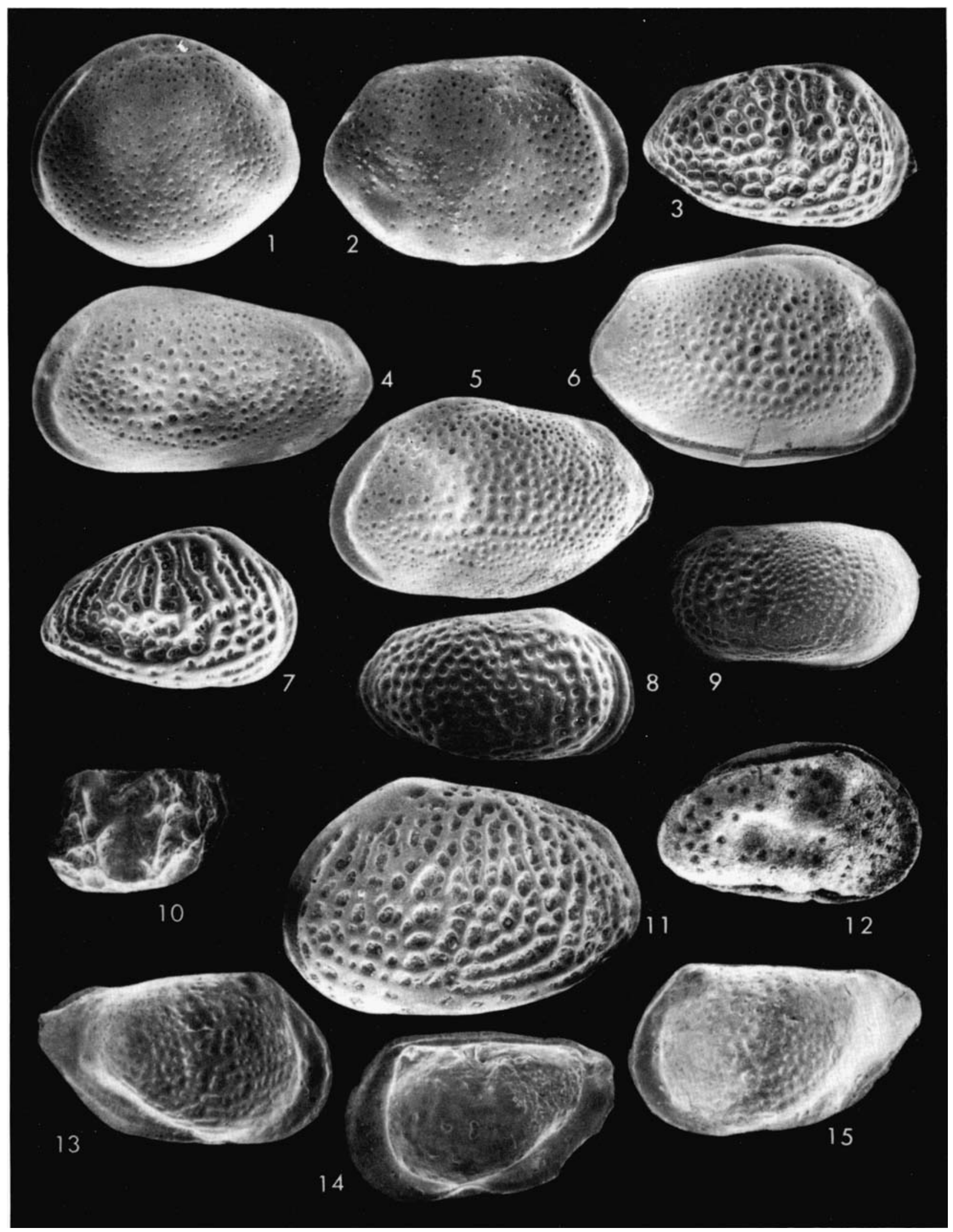


anterior vestibule narrow; marginal pore canals few, simple and straight. Hinge antimerodont, an ocular sinus is situated behind the anterior terminal element. A vertical, slightly arcuate row of four small, rounded adductor scars and a V-shaped frontal scar is situated slightly anterior of the mid point. Sexual dimorphism not observed.

Remarks. Micrommatocythere gen. nov. bears a superficial resemblance to some species of the genera Monoceratina and Pseudocythere, but differs in possessing an eye tubercle, an antimerodont hinge and four adductor muscle scars. It is placed in the family Cytheruridae on the basis of the hinge, muscle scar arrangement and the posterodorsal caudal process. Monoceratina saxonica Schmidt, 1954, from the middle and upper Kimmeridgian of N.W. Germany and Bythocythere? sp. cf $B$. nescia of Neale (1962) from the Lower Hauterivian Speeton Clay, may prove to belong here.

Micrommatocythere edmundi sp. nov.

(Pl. 1, figs. 13-15; Fig. 4.)

Derivation of name. After the author's son.

Diagnosis. Small punctate species of Micrommatocythere with drawn out caudal process and weakly developed ala.

Holotype. MPK 3659, carapace, from the middle part of the cymodoce ammonite Zone $(G$. dissimilis ostracod Zone), Bed 11, of the Lower Kimmeridge Clay at a depth of $114.9 \mathrm{~m}$ in the North Wootton Borehole.

Description. Carapace small and thinly shelled. Dorsal margin straight and subparallel with the sinuous ventral margin which has a marked mid-ventral concavity best seen when viewed internally. Anterior margin broadly rounded. Posterior cardinal angle prominent and posterior margin drawn out in a dorsally situated caudal process. The greatest width is posterior of mid-length and the highest point is at the anterior cardinal angle. Surface finely punctate. Eye tubercle small, but distinct.
The posteroventral area exhibits a weakly developed ala which partly obscures the marked mid-ventral concavity. An extremely weak sulcus is present. Internal margin moderately broad. Anterior vestibule narrow. Marginal pore canals few, straight and simple, 9 anteriorly and 4 posteriorly. Hinge antimerodont. A vertical, slightly arcuate row of four small, round adductor muscle scars and a V-shaped frontal scar are situated slightly anterior of mid-length.
Dimensions $(\mathrm{mm})$
Length
Height
Holotype car., MPK 3659
0.26
0.15

Remarks. The fact that this species has a small, but distinct eye tubercle and an antimerodont hinge distinguishes it from several species of Monoceratina and Pseudocythere which it superfically resembles. The present form is very similar to Monoceratina saxonica Schmidt from the Kimmeridgian of N.W. Germany, but

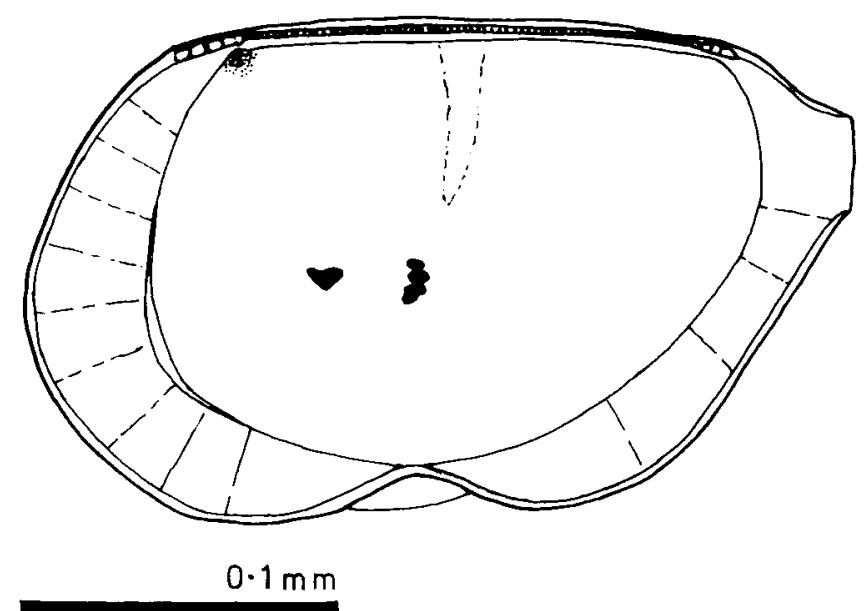

Fig. 4. Micrommatocythere edmundi sp. nov., paratype, RV internal view, MPK 3932.

Explanation of Plate 2

All figures are $\times 100$ unless otherwise specified

Figs. 1-4. Macrodentina (Polydentina) woottonensis sp. nov.: fig. 1, RV, paratype, MPK $3671(\times 85)$; fig. 2, LV, holotype, MPK $3672(\times 75)$; fig. 3, spinose LV, paratype, MPK $3671(\times 85)$; fig. 4, car., dorsal view, paratype, MPK $3673(\times 80)$. Bed 45 (hudlestoni ammonite Zone) depth $24.6 \mathrm{~m}$.

Figs. 5-8. Mandelstamia (Xeromandelstamia) horrida sp. nov.: fig. 5, 9 RV, paratype, MPK 3663; fig. 6.0 LV, holotype, MPK 3664; fig. 7, RV, dorsal view showing hinge, paratype, MPK 3665; fig. 8, car., dorsal view, paratype, MPK $3666(\times 160)$. Bed 39 (scitulus atmmonite Zone), depth $42.5 \mathrm{~m}$.

Figs. 9-10. Mandelstamia (Xeromandelstamia) maculata Kilenyi: fig. 9,9 RV, MPK 3657 ( $\times 75$ ); fig. 10, o LV, MPK $3678(\times 55)$. Bed 42 (hudlestoni ammonite Zone), depth $35.1 \mathrm{~m}$.

Figs. 11-12. Paranotacythere (Unicosta) effusa sp. nov.: fig. 11, RV, paratype, MPK 3669; fig. 12, LV, holotype, MPK 3670 . Bed 40 (wheatleyensis ammonite Zone), depth $4(0.4 \mathrm{~m},(\times 150)$.

Fig. 13. Eocytheropteron aquitanum (Donze): LV, MPK 3658, Bed 44 (hudlestoni ammonite Zone), depth $30.9 \mathrm{~m}$. 


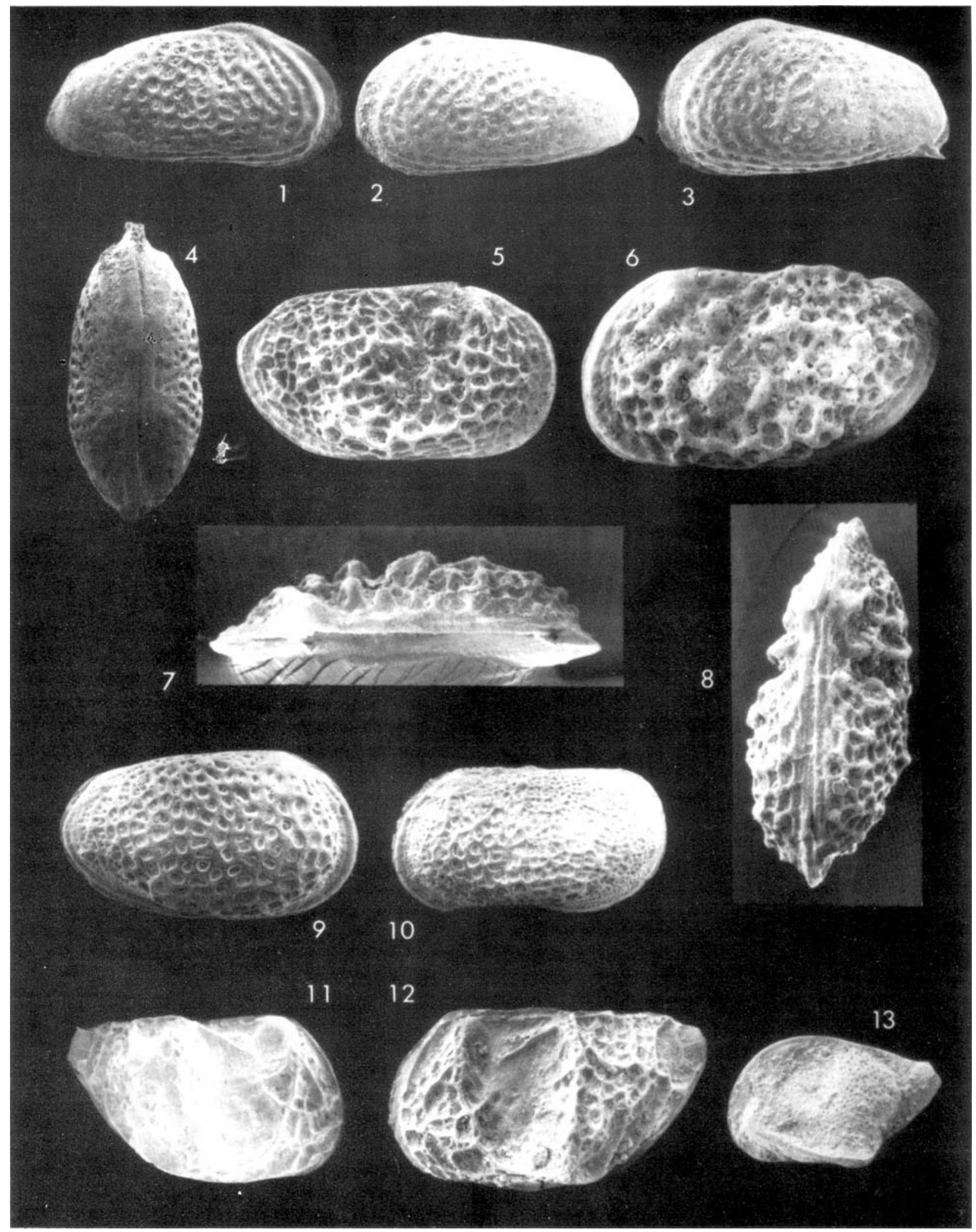


differs in outline, particularly when viewed dorsally and in being weakly alate. Micrommatocythere edmundi $\mathrm{sp}$. nov. has been recovered from several horizons from the $P$. baylei and $A$. mutabilis ammonite Zones $(G$. dissimilis and $M$. proclivis ostracod Zones), Lower Kimmeridgian, Beds 1-17 of Gallois \& Cox (1976).

Genus Paranotacythere Bassiouni, 1974 Paranotacythere (Unicosta) effusa sp. nov. (PI. 2, figs. 11-12)

Derivation of name. Latin, effusa profuse, relating to its flood occurrence in Bed 40 of the Kimmeridge Clay of the North Wootton Borehole.

Diagnosis. A robust, reticulate species of Paranotacythere (Unicosta) with smooth sulcus and caudal process. A very conspicuous posteroventral rib is joined to the main $U$-shaped rib system which surrounds the sulcus, at a very prominent tubercle, which may bear a spine. It extends towards the posterior a short distance, partly obscuring the ventral margin, before bifurcating.

Holotype. MPK 3670 , LV, from the lower part of the wheatleyensis ammonite Zone (M. maculata ostracod Zone), Bed 40, of the Upper Kimmeridge Clay at a depth of $40.4 \mathrm{~m}$ in the North Wootton Borehole.

Description. Carapace large and robust. Dorsal margin straight; ventral margin convex, curving smoothly upward to the blunt caudal process; anterior margin broadly rounded. The lateral surface is ornamented by a system of ribs and intercostal reticulation. The sulcus is wide and smooth and the caudal process is also without ornamentation, and separated from the reticulate part of the lateral surface by a subdued, arcuate rib. The main rib system is $U$-shaped, about the sulcus into which an obliquely orientated dorsal rib runs. A mid-dorsal tubercle is situated at the junction between the vertical posteromedian and dorsal ribs. The posteroventral part of the U-shaped rib system bears a prominent tubercle, surmounted by a short spine, from which extends a distinct rib that partly overhangs the ventral margin before bifurcating, one rib curving upward to merge with the reticulation in the posteromedian area while the other runs parallel to the ventral margin as far as the arcuate ridge in front of the caudal process. A subdued rib runs longitudinally, above mid-height, in the posteromedian area, joining the U-shaped rib system with the arcuate rib at the caudal process. A distinct eye tubercle is present. Internally, features are as for the genus and subgenus as defined by Bassiouni (1974). Males are slightly more elongate than the females.

$\begin{array}{ccc}\text { Dimensions (mm) } & \text { Length } & \text { Height } \\ \text { Holotype LV, MPK } 3670 & 0.36 & 0.20\end{array}$

Remarks. Paranotacythere (Unicosta) effusa is closely related to the Lower Kimmeridgian species $P$. $(U)$ extendata and $P$. (U.) interrupta. It differs from the former in being larger, having a smooth sulcus, a more subdued dorsal rib and in the detail of the rib system. It is separated from $P$. (U.) interrupta by size and organisation of the rib system.

\section{?Family Loxoconchidae Sars, 1925 \\ Genus Mandelstamia Ljubimova, 1955 \\ Mandelstamia (Xeromandelstamia) horrida sp. nov. (PI. 2, figs. 5-8)}

Derivation of name. Latin, horridus, rough.

Diagnosis. A species of Mandelstamia (Xeromandelstamia) ornamented with rough tubercles and reticulation. Deeply sulcate with a large subcentral tubercle.

Holotype. MPK 3664, male LV, from the uppermost part of the scitulus ammonite Zone, Bed 39, of the Upper Kimmeridge Clay at a depth of $42.5 \mathrm{~m}$ in the North Wootton Borehole.

Description. Dorsal and ventral margins straight and subparallel; posteroventral margin gently curved upwards to the rounded posterior margin; anterior margin broadly rounded. Surface ornamented by a series of small irregular tubercles and a reticulation which gives the surface a very rough appearance. A deep sulcus is present anterior of mid length in which a large, high, conical, subcentral tubercle is situated. Inner margin moderately broad, selvage well developed, anterior and posteroventral vestibules very narrow. Marginal pore canals few, straight and simple. Muscle scars not observed. Hinge, as for subgenus with crenulate terminal elements and smooth median bar/groove. Sexual dimorphism extremely pronounced, the male being much larger and more inflated than the female.
Dimensions (mm)
Holotype of LV, MPK 3664
Paratype 9 MPK 3663
Length
0.62
Height
0.36
0.55
0.31

Remarks. The ornament of Mandelstamia $(X)$ horrida serves to distinguish the species from all other members of the genus. The species was found to be confined to the upper part of the P. scitulus ammonite Zone (Upper Kimmeridgian), Bed 39 of Gallois \& Cox (1976) where it occured in flood proportions.

Family Cytherideidae Sars, 1925

Subfamily Cytherideinae Sars, 1925

Genus Galliaecytheridea Oertli, 1957

Galliaecytheridea mandelstami kilenyii ssp. nov.

(Pl. 1, figs. 5-6)

1969 Galliaecytheridea cf. mandeistami (Ljubimova); Kilenyi: 126-127, pl. 26, figs. 1-9, Text-fig. 3g. 1978 Galliaecytheridea cf. mandelstami (Ljubimova); Kilenyi: 274, pl. 6, figs. 11-12, Table 2 .

Derivation of name. In honour of Dr. T. Kilenyi who has carried out extensive work on the Ostracoda of the Kimmeridge Clay. 
Diagnosis. A subspecies of Galliaecytheridea mandelstami (Ljubimova) with ovoid, slightly elongate carapace; marked posterior cardinal angle; posterior margin extended into a rounded point at mid height; punctate ornament coarse in the median area becoming finer towards the margins.

Holotype. MPK 3655, carapace, from the upper part of the mutabilis ammonite Zone (lower part of the $G$. elongata ostracod Zone), Bed 22, of the Lower Kimmeridge Clay at a depth of $89.7 \mathrm{~m}$ in the North Wootton Borehole.

$\begin{array}{ccc}\text { Dimensions (mm) } & \text { Length } & \text { Height } \\ \text { Holotype car., MPK } 3655 & 0.58 & 0.36\end{array}$

Remarks. Kilenyi (1969) has described this form in details under the name Galliaecytheridea of. mandelstami (Ljubimova, 1955). The subspecies $G$. mandelstami kilenyii ssp. nov. differs from $G$. mandelstami mandelstami in being smaller and more elongate. Its stratigraphical distribution is confined to the higher part of the A mutabilis ammonite Zone (the lower part of the G. elongata ostracod Zone), Beds 18-23 of Gallois \& Cox (1976).

\section{ACKNOWLEDGEMENTS}

The author wishes to thank Dr. R.C. Whatley, Dr. B. Cox and Mr. R. Gallois for helpful comments and criticism at various times during the preparation of this paper. It is published with permission of the Director of the Institute of Geological Sciences (N.E.R.C.).

\section{REF ERENCES}

Christensen, O.B., 1974. Marine communications through the Danish Embayment during uppermost Jurassic and lowermost Cretaceous. Geoscience and Man, Baton Rouge, 6, 99 115.

Christensen, O.B. \& Kileny, T.I. 1970. Ostracod biostratigraphy of the Kimmeridgian in northern and western Europe. Bull. Geol. Surv. Denmark, Copenhagen, ser. II. 95, $65 \mathrm{pp}$.

Cope. J.C.W. 1974. Upper Kimmeridgian ammonite taunas of the Wash area and a subzonal scheme for the lower part of the Upper Kimmeridgian. Bull. Geol. Surv. G.B., London, 47, 29-37.

Cox, B.M. \& Gallois, R.W. 1981. The stratigraphy of the Kimmeridge Clay of the Dorset type area and its correlation with some other Kimmeridgian sequences. Rep. Inst. (ieol. Sici., London, 80/4, 44 pp.

Donze, P. 1960. Les formations du Jurassique terminal dans la partie nord-ouest de l'île d'Oléron (Charente-Maritime). Ann. Univ. Lyon. Lyon, C12,5-30.

Gallois, R.W. 1979a. Geological investigations for the Wash Water Storage Scheme. Rep. Inst. Geol. Sci., London, 78/19, 74 pp.

Gallois, R.W. 1979b. The Kimmeridge Clay in Norfolk. Bull. geol. Soc. Norfolk, Norwich, 31, 45-68.

Gallois, R.W. \& Cox, B.M. 1974. Stratigraphy of the Upper Kimmeridge Clay of the Wash area. Bull. Geol. Surv. (3.B., London, 47, 1-28.
Gallois, R.W. \& Cox, B.M. 1976. The Stratigraphy of the Lower Kimmeridge Clay of eastern England. Proc. Yorks. Geol. Soc., Leeds, 41 (1), 13-26.

Glashoff, H. 1964. Ostrakoden-Faunen und Paläogeographie im Oxford NW-Europas. Paläont. $Z$, Stuttgart, 38 (1/2), $28-65$.

Kent, P.E. 1947. A deep boring at North Creake, Norfolk. Geol. Mag., London, 84 (1), 2-18.

Kilenyi, T.1. 1965. Oertliana, a new Ostracod genus from the Upper Jurassic of North-West Europe. Palaeontology, London, 8 (3), 572-576.

Kilenyi, T.I. 1969. The Ostracoda of the Dorset Kimmeridge Clay. Palaeontology, London, 12 (1), 112-160.

Kilenyi, T.I. 1978. The Jurassic Part III Callovian-Portlandian. In Bate, R. \& Robinson, E. (Eds.), A stratigraphical index of British Ostracoda. Geol. Jour. Sp. Issue, London, 8, $259-298$.

Malz, H. 1958a Nodophthalmocythere n. gen. (Ostrac. Ob. Jura), nebst einer Abgrenzung gegen ähnliche Gattungen. Senck. leth., Frankfurt, 39 (1/2), 119-133.

Malz, H. 1958b. Die Gattungen Macrodentina und einige andere Ostracoden-Arten aus dem Oberen Jura von NWDeutschland, England und Frankreich. Abh. senckenb. naturf. Ges., Frankfurt, 497, 1-67.

Neale, J.W. 1962. Ostracoda from the type Speeton Clay (Lower Cretaceous) of Yorkshire. Micropaleontology, New York, 8, 425-484.

Oertli, H.J. 1963. Mesozoic Ostracod Faunas of France. 57 pp., Leiden.

Pringle, J. 1923. On the concealed Mesozoic rocks in southwest Norfolk. In Geol. Surv. Summ. Prog. for 1922, London, Appendix I, 126-139.

Rose, C.B. 1835. A sketch of the geology of western Norfolk. London \& Edinburgh Phil. Mag. \& Jour., ser. 3, 7, 171-182.

Whatley, R.C. 1965. Callovian and Oxfordian Ostracoda from England and Scotland. Unpublished Ph.D. Thesis, University of Hull, $589 \mathrm{pp}$.

Whitaker, W., Skertchly, S.B.J. \& Jukes-Browne, A.J. 1893. The geology of south-western Norfolk and of northern Cambridge. Mem. Geol. Surv. England and Wales, London, Sheet 65 (Old Series), $178 \mathrm{pp}$

Woodward, H.B. 1895. The Jurassic rocks of Britain. Vol. V. The middle and upper oolitic rocks of England (Yorkshire excepted). Mem. Geol. Surv. U.K., London, 499 pp. 